\title{
Index of norms and ratings published in the Psychonomic Society journals
}

\author{
ROBERT W. PROCTOR and KIM-PHUONG L. VU \\ Purdue University, West Lafayette, Indiana
}

\begin{abstract}
The journals of the Psychonomic Society have served as outlets for numerous stimulus norms and ratings. Such norms are useful to researchers in a variety of areas for manipulating and controlling stimulus attributes. This article presents an index of 142 norms published in the Society's journals, categorized according to the types of materials and ratings that are included in each.
\end{abstract}

In many areas of psychological research, stimuli must be selected according to some attribute to achieve appropriate experimental control. Stimuli may be selected with respect to an attribute in order to use it as an independent variable, to avoid confounds of it with other variables of interest, or to examine the effects of it in relation to other variables. For example, it is customary to manipulate frequency of use as a factor, or to control for it as a potentially confounding variable, when one is examining perception or memory of words (e.g., Rao \& Proctor, 1984). This is typically accomplished by consulting word frequency norms, such as those developed by Kučera and Francis (1967). Numerous other properties of words, letters, pictures, symbols, and so forth, are of interest as well, and careful selection of stimuli according to a number of attributes is often necessary. Over the years, many norms for stimulus materials have been published to enable researchers to select stimuli that satisfy the desired constraints.

Since the 1960s, the Psychonomic Society's journals have served as repositories for norms and ratings of various types. In the late $60 \mathrm{~s}$ and early $70 \mathrm{~s}$, a large portion of the Psychonomic Monograph Supplements was devoted to such norms. In more recent years, Behavior Research Methods, Instruments, \& Computers (BRMIC) has been the journal in which most norms are published, although norms have occasionally appeared in the other journals as well. Given the vast collection of norms that have been published in the journals, it should be of value to researchers to have an index of them. The purpose of this paper is to provide such an index, alphabetized by author, along with a table that classifies the norms according to their content.

The index follows in the tradition of Brown's (1976) catalog, which contains detailed information summariz-

We thank Doris Aaronson for comments on an earlier version of this paper. Correspondence should be sent to R. W. Proctor, Department of Psychological Sciences, Purdue University, W. Lafayette, IN $47907-$ 1364 (e-mail: proctor@psych.purdue.edu). ing 172 studies that present information on scaled verbal materials, and Bradshaw's (1984) guide, which provides an index of 119 studies, mostly post-1960, that include norms, scales, ratings, or lists of verbal materials for use in experiments. Our index differs from theirs in not being restricted to verbal materials and in listing only articles published in BRMIC and the other Psychonomic journals. These journals include Memory \& Cognition, Perception \& Psychophysics, Psychonomic Bulletin \& Review, and its earlier incarnations, Psychonomic Science and the Bulletin of the Psychonomic Society, as well as the Psychonomic Monograph Supplements mentioned above. In addition to searching the indexes of each volume of the respective journals, we consulted the earlier norm indexes by Brown and Bradshaw. We also searched PsycINFO, using the keywords norms, ratings, confusion matrices, and their variants. Our primary criterion for inclusion of articles was that they report characteristics for a stimulus set that might be of use and value to researchers. The index should be relatively complete, although it certainly is possible that some norms were overlooked.

The entries in the index itself are presented in alphabetical order by author. In addition, the articles are classified in Table 1 according to the following categories for the English Language: Word Frequency; Word Associations; Word Meanings; Anagrams and Completion Norms; Grapheme-Phoneme Correspondence; Imagery, Concreteness, Familiarity, and Related Measures; Letter Frequency; Letter Strings; Homographs, Homophones, and Homonyms; Typicality and Category Judgments; Names; Pictures and Symbols; Alphabetic Confusion Matrices; and Recall and Recognition. In addition, categories for Word and Picture Norms for Languages other than English and Other (norms that do not fit into the categories above) are included. For each study in a category we have indicated the characteristics of the stimuli that were scaled and the size of the corpus. Abstracts of the studies are not included, as in Brown's (1976) article, because of the widespread availability of computerized indexing services such as PsycINFO, which can be consulted if more information about the norms in question is desired. 


\section{REFERENCES}

Bloom, P. A., \& Fischler, I. (1980). Completion norms for 329 sentence contexts. Memory \& Cognition, 8, 631-642.

Bradshaw, J. L. (1984). A guide to norms, ratings, and lists. Memory \& Cognition, 12, 202-206.

Brown, A. S. (1976). Catalog of scaled verbal material. Memory \& Cognition, 4 (1 B), 1S-45S.

KENT, G. H., \& RosanOFF, A. J. (1910). A study of associations in insanity. American Journal of Insanity, 67, 37-96, 317-390.

KuČERA, H., \& FrancIS, W. N. (1967). Computational analysis of present-day American English. Providence, RI: Brown University Press.

PAlermo, D. S., \& Jenkins, J. J. (1964). Word association norms: Grade school through college. Minneapolis: University of Minnesota Press.

RaO, K. V., \& Proctor, R. W. (1984). Study-phase processing and the word frequency effect in recognition memory. Journal of Experimental Psychology: Learning, Memory, \& Cognition, 10, 386-394.

RuSSELl, W. A., \& JENKINS, J. J. (1954). The complete Minnesota norms for responses to 100 words from Kent-Rosanoff word association test (Tech. Rep. No. 11, Contract N8-ONR-66216, ONR). Minneapolis: University of Minnesota Press.

SNODGRASS, J. G., \& VANDERWART, M. (1980). A standardized set of 260 pictures: Norms for name agreement, image agreement, familiarity, and visual complexity. Journal of Experimental Psychology: Human Learning \& Memory, 6, 174-215.

ThORNDIKE, E. L., \& LoRGE, I. (1944). The teacher's word book of 30,000 words. New York: Columbia University, Teachers College, Bureau of Publications.

UNDERwoOd, B. J., \& Schulz, R. W. (1960). Meaningfulness and verbal learning. Chicago: Lippincott.

Table 1

Categories of Norms and Ratings

\begin{tabular}{lll}
\hline \multicolumn{1}{c}{ Study } & \multicolumn{1}{c}{ Category } & \multicolumn{1}{c}{ Corpus } \\
\hline Bowen (1971) & Printed frequency & 420 conceptual nouns \\
Brown (1984) & $\begin{array}{l}\text { Conversational frequency } \\
\text { Availability (the frequency with which a word is used } \\
\text { Keenan \& Benjafield (1994) }\end{array}$ & $\begin{array}{l}\text { Oxford English Dictionary } \\
\text { in the definition of other words) }\end{array}$
\end{tabular}

Rudell (1993)

Amster (1967)

Biersdorff \& Solso (1973)

Duncan \& Wood (1966)

Garskof, Houston, \& Mednick (1967)

Geen \& Stonner (1975)

Gerjouy \& Gerjouy (1965)

Lovelace, Reid, \& Hunt (1981)

S. S. Shapiro (1966)

S. 1. Shapiro \& Palermo (1968)

Stark (1972)

Tresselt \& Mayzner (1964)

Winters \& Kahn (1970)

Winters \& Kahn (1971)

Britton (1978)

Dale \& Fenson (1996)

Ferraro \& Kellas (1990)

Griffin (1999)

Nickerson \& Cartwright (1984)

Roberts (1968)

Solso (1971)

Wilson (1988)
Frequency of word usage and perceived word difficulty

\section{WORD ASSOCIATIONS}

Associative responses to mutually related pairs of words for children and adults

Word associations labeled by responses

Successive word associations

Single and multiple associations: Overlap and direct associative strength values

Associates to verbs connoting violence

Word associations for institutionalized adolescent retardates

Free associations to conceptually structured word triads for elementary school, high school, and college students

Word association norms for 12- to 13-year-olds

Atlas of normative free association data

Synonym responses to words that have synonyms as their free association primaries

Word association norms as a function of age from 18 to 87 years

Word association norms for adolescent mental retardates, grade school, and undergraduate normals

Word association norms for adolescent mental retardates and normal children

\section{WORD MEANINGS}

Lexical ambiguity as indicated by number of meanings Lexical development norms for young children Subjective number of meaning for words and pseudowords

Frequency of meaning use for ambiguous and unambiguous words

Generated meanings for words

Meaningfulness of sense impression adjectives

Meaningfulness ratings for colors and color words MRC psycholinguistic database
Four sets of 50 words from Kučera and Francis (1967)

Word pairs from Russell and Jenkins (1954) and Palermo and Jenkins (1964) norms

Recodified Palermo and Jenkins (1964) word association norms

20 Kent-Rosanoff (1910) words

480 word pairs

20 words

100 Kent-Rosanoff (1910) words

40 word triads

82 words

20 collections of normative discrete free association data

100 words

Kent-Rosanoff (1910) words

200 words

200 words

257 words

680 words

576 words and orthographically legal pseudowords

211 words

90 words

40 sense impression adjectives

10 colors and 10 color words

150,837 words and 26 linguistic and psycholinguistic attributes 
Table 1 (Continued)

\begin{tabular}{|c|c|c|}
\hline Study & Category & Corpus \\
\hline \multicolumn{3}{|c|}{ ANAGRAMS AND COMPLETION NORMS } \\
\hline Bloom \& Fischler (1980) & Completion norms for sentence contexts & 329 sentence contexts \\
\hline Erickson, Gaffney, \& Heath (1987) & $\begin{array}{l}\text { Difficulty and familiarity norms for single- } \\
\text { solution word fragments }\end{array}$ & 192 word fragments \\
\hline Gibson \& Brooks ( 1993 ) & Word fragments with unique completions & 4,741 word fragments \\
\hline Gibson \& Watkins (1988) & Word fragments with unique completions & 1,086 word fragments \\
\hline Graf \& Williams (1987) & Completion norms for three-letter word stems & 40 three-letter word stems \\
\hline Hamberger, Friedman, \& Rosen (1996) & $\begin{array}{l}\text { Completion norms for sentence contexts } \\
\text { from young and older adults }\end{array}$ & 198 sentence contexts \\
\hline R. Olson \& Schwartz (1967) & $\begin{array}{l}\text { Single and multiple solutions for five-letter } \\
\text { words }\end{array}$ & 3 lists (five-letter words) \\
\hline Schwanenflugel (1986) & $\begin{array}{l}\text { Completion norms for final words of } \\
\text { sentences }\end{array}$ & $\begin{array}{l}\text { Subset of Bloom \& Fischler (1980) sentence- } \\
\text { completion norms }\end{array}$ \\
\hline Shaw (1997) & Unprimed word-stem completion norms & 914 multicompletion three-letter word stems \\
\hline Tresselt \& Mayzner (1966) & $\begin{array}{l}\text { Solution times for solution words and } \\
\text { associated anagrams }\end{array}$ & $\begin{array}{l}134 \text { solution words and } 378 \text { associated } \\
\text { anagrams }\end{array}$ \\
\hline
\end{tabular}

Berndt, Reggia, \& Mitchum (1987)

Cowan (1986)

Martin, Jones, Nelson, \& Nelson (1981)

Ziegler, Stone, \& Jacobs (1997)

\section{GRAPHEME-PHONEME CORRESPONDENCE}

Probabilities for grapheme-to-phoneme correspondences

Consonant-cluster-free monosyllabic words Words with multiple phonemic representations

Database for feedforward inconsistency (multiple ways to pronounce a spelling) and feedback inconsistency (multiple ways to spell a pronunciation)
17,310 English words

Matrix of English phonemes

52 strong and 62 weak heteronyms; 246 polyphones

2,694 monosyllabic words

\section{IMAGERY, CONCRETENESS, FAMILIARITY, AND RELATED MEASURES}

Altarriba, Bauer, \& Benvenuto (1999)

Benjafield, Frommhold, Keenan, Muckenheim, \& Mueller (1993)

Benjafield \& Muckenheim (1989)

Friendly, Franklin, Hoffman, \& Rubin (1982)

Gilhooly \& Hay (1977)

Gilhooly \& Logie (1980a)

Gilhooly \& Logie (1980b)

Hunt (1978)

Kerr \& Johnson (1991)

Stratton, Jacobus, \& Brinley (1975)

Walker (1970)

Gilhooly (1978)

Mayzner \& Tresselt (1965)

Mayzner, Tresselt, \& Wolin (1965a)

Mayzner, Tresselt, \& Wolin (1965b)

Mayzner, Tresselt, \& Wolin (1965c)

Solso (1979)

Solso, Barbuto, \& Juel (1979)

Solso \& Juel (1980)
Imagery, concreteness, context availability, and word associations

Imagery, concreteness, goodness, and familiarity

Imagery, concreteness, goodness, and familiarity

Imagery, concreteness, orthographic variable, and grammatical usage

Imagery, concreteness, age-of- acquisition, familiarity, and meaningfulness

Age-of-acquisition, imagery, concreteness, familiarity, and ambiguity

Meaning-dependent imagery, age of acquisition, familiarity, and concreteness

Imagery for taxonomic categories

Familiarity, concreteness, meaningfulness, imageability, imagery modality, and word associations for blind and sighted people

Age-of-acquisition, imagery, familiarity, and meaningfulness

Imagery ratings

\section{LETTER FREQUENCY}

Bigram statistics

Single-letter and bigram frequency

Trigram frequency

Tetragram frequency

Pentagram frequency

Positional frequency and versatility of letters

Bigram and trigram frequencies and versatilities

Positional frequency and versatility of bigrams
155 abstract words, 100 concrete words, and 71 emotion words

500 proverbs

1,046 words from the Oxford English

Dictionary

1,080 words from Toronto Word Pool

205 five-letter words with anagram solutions

1,944 words of varying length and frequency

387 ambiguous words

90 category names

161 nouns

543 five- and six-letter words

338 nouns

205 five-letter words with single solution anagrams

20,000 English words

20,000 English words

20,000 English words

20,000 English words

Six-, seven-, and eight-letter words from Kučera and Francis (1967) norms

577 bigrams and 6,140 trigrams

577 bigrams 
Table 1 (Continued)

\begin{tabular}{lll}
\hline \multicolumn{1}{c}{ Study } & \multicolumn{1}{c}{ Category } & \multicolumn{1}{c}{ Corpus } \\
\hline Solso \& King (1976) & $\begin{array}{l}\text { Frequency and versatility of letters and letter } \\
\text { combinations }\end{array}$ & Kučera and Francis (1967) norms \\
Stadtlander (1997) & $\begin{array}{l}\text { Word neighborhood and frequency } \\
\text { Brigram versatility and frequency }\end{array}$ & $\begin{array}{l}\text { Thorndike-Lorge (1944) and Underwood \& } \\
\text { Topper, Macey, \& Solso (1973) }\end{array}$ \\
& \multicolumn{2}{c}{ LETTER STRINGS (1960) }
\end{tabular}

Costantini \& Blackwood (1968)

Hunt (1977)

Ley \& Karker (1974)

Ley \& Tesiny (1975)

Lippman \& Kintz (1968)

Noble (1967)

Nodine \& Hardt (1969)

Scott \& Baddeley (1969)

S. S. Shapiro (1964)

Taylor (1970)

Hirata \& Bryden (1971)

Lachman \& Laughery (1965)

Rubin (1981)

Amster \& Keppel (1966)

Jones (1980a)

Jones (1980b)

Azuma (1996)

Gawlick-Grendell \& Woltz (1994)

Geis \& Winograd (1974)

Gorfein, Viviani, \& Ledo (1982)

Nelson, McEvoy, Walling, \& Wheeler (1980)

Twilley, Dixon, Taylor, \& Clark (1994)

Warren, Bresnick, \& Green (1977)

Wollen, Cox, Coahran, Shea, \& Kirby (1980)

Ferreira \& Cutting (1997)

G. A. Olson \& Kausler (1971)

Whalen \& Zsiga (1994)

Ashcraft (1978)

Bjorklund, Thompson, \& Ornstein (1983)

Chiarello, Shears, \& Lund (1999)

\section{CCCs, CVCs, and CVCVCs}

Meaningfulness ratings

Meaningfulness values

Pronunciabilty ratings

Associative reaction time, meaningfulness, and pronunciability ratings

Ranks for pronunciability and ease of learning

Pronunciability ratings

Pronunciation latencies for CVC trigrams

Acoustic confusability values

Meaningfulness values for grade-school-aged children

CVC trigram meaningfulness

Letter Sequences and Approximation to English

Letter sequences varying in approximation to English

Letter association and sequence norms

Order approximation and orthographic neighborhood ratio

\section{Other}

Letter association norms for children English palindromes (strings of letters that spell the same word forward or backwards)

Heteropalindromes (strings of letters that form words when read forward and backward)

\author{
$343 \mathrm{CCC}$ trigrams \\ $300 \mathrm{CCC}$ trigrams \\ 319 CVCVC words and paralogs \\ $382 \mathrm{CVCVCs}$ and paralogs \\ $20 \mathrm{CVC}$ trigrams \\ $100 \mathrm{CVC}$ trigrams \\ $2,100 \mathrm{CVC}$ trigrams \\ $1,172 \mathrm{CCC}$ trigrams \\ 52 CVC trigrams \\ 210 trigrams and 20,000 words
}

10010 -letter sequences

All letters of the alphabet

925 nouns

26 single-letter and 676 double-letter stimuli 81 palindromes from Chambers Twentieth Century Dictionary

145 heteropalindromes

\section{HOMOGRAPHS, HOMOPHONES, AND HOMONYMS}

\section{Homographs}

Familiarity and relatedness among meanings

Meaning dominance norms

Semantic encoding variability

Four continuous word associations to each homograph

Meaning dominance norms

Relative meaning frequency

Definitional dominance

Frequency and concreteness of homograph meanings

\section{Homophones and Homonyms}

Pictures and questions for elicitation of homophones

Orthographic distinctiveness of homonyms

Subjective familiarity of English word/name homophones

\section{TYPICALITY AND CATEGORY JUDGMENTS}

\section{Typicality}

Property norms for typical and atypical items

Category typicality norms for 12 natural language categories for kindergarten, thirdgrade, sixth-grade, and college students Imageability and distributional typicality measures
110 homographs

120 homographs

50 homographs

107 homographs

320 homographs

566 homographs

20 English homographs

120 homographs

93 pictures and 108 questions

139 homonym pairs

40 homophones

121 words, 17 categories

12 natural languages

1,197 words 
Table 1 (Continued)

\begin{tabular}{ll}
\hline \multicolumn{1}{c}{ Study } & \multicolumn{1}{c}{ Category } \\
\hline Gruenenfelder (1984) & $\begin{array}{l}\text { Typicality ratings for exemplars and } \\
\text { categories }\end{array}$ \\
Katz (1983) & $\begin{array}{l}\text { Dominance and typicality norms } \\
\text { Family resemblance scores of category mem- } \\
\text { bers used to derived typicality ratings for } \\
\text { Maridaki-Kassotaki (1997) }\end{array}$ \\
Uyeda \& Mandler (1980) & $\begin{array}{l}\text { Prototypicality norms for semantic categories } \\
\text { Chaffin \& Herrmann (1981) }\end{array}$ \\
Hunt \& Hodge (1971) & $\begin{array}{l}\text { Ratings of antonymy, synonymity, subordina- } \\
\text { tion, coordination, and similarity for word pairs }\end{array}$ \\
Loess, Brown, \& Campbell (1969) & $\begin{array}{l}\text { Category-item frequency, and category-name } \\
\text { meaningfulness }\end{array}$ \\
Posnansky (1978) & $\begin{array}{l}\text { Norms for items in taxonomic categories } \\
\text { Category norms for children Grades 2-6 }\end{array}$ \\
S. I. Shapiro \& Palermo (1970) & Conceptual organization and class membership \\
Conley, Burgess, \& Hage (1999) & NaMES \\
Surprenant et al. (1999) & $\begin{array}{l}\text { Two corpora of proper names, one based on } \\
\text { U.S. phone book listing, and the other derived } \\
\text { from a database of Usenet text }\end{array}$ \\
Fechmeister, King, Gude, \& Opera-Nadi & $\begin{array}{l}\text { Familiarity and pronunciability of nouns and } \\
\text { names } \\
\text { Ratings of frequency, familiarity, ortho- } \\
\text { graphic distinctiveness, and pronunciability }\end{array}$
\end{tabular}

893 exemplars of 93 categories

170 nouns and 459 properties

4 categories of 12 words

840 words and 28 categories

2 sets of 20 stimulus pairs

84 categories

30 taxonomic categories

25 categories

100 conceptual categories

More than 10,000 names from the U.S. phone book corpus and more than 5,000 names from the Usenet-based corpus

199 surnames and 199 nouns

192 surnames

\section{PICTURES AND SYMBOLS}

\section{Snodgrass and Vanderwart Pictures}

Berman, Friedman, Hamberger, \& Snodgrass (1989)

Snodgrass \& Poster ( 1992)

Snodgrass \& Yuditsky ( 1996)

Boutsen, Lamberts, \& Verfaillie (1998)

Danks (1972)

de Bruijn, McDougall, \& Curry ( 1999)

McDougall, Curry, \& de Bruijn (1999)

Verfaillie \& Boutsen (1995)

Boles \& Clifford (1989)

Geyer (1977)

Geyer \& Gupta (1981)

Keren \& Baggen (1981)

Townsend (1971a)

Townsend (1971b)

van der Heijden, Malhas, \&

van den Roovaart (1984)

Craig (1979)

Kikuchi, Yamashita, Sagawa, \& Wake (1979)

Loomis (1974)
Name agreement, familiarity, and visual complexity of line drawings for children and adults

Visual-word recognition threshold for screenfragmented names

Naming times and age-of-acquisition ratings for pictures

\section{Objects, Symbols, Figures}

Recognition times for depth-rotated objects Associative responses to novel figures Database for selection of icon and symbol sets Concreteness, complexity, meaningfulness, familiarity, and semantic distance for symbols Full-color images of depth-rotated objects, with up to 11 perspective views of each object

\section{ALPHABETIC CONFUSION MATRICES Visual}

Upper- and lowercase alphabetic similarity

Recognition and confusion of lowercase alphabet

Confusion matrices for dot matrix and conventional font capital letters

Feature list for uppercase letters based on interletter confusion matrices

Alphabetic confusion matrix for individuals Alphabetic confusion matrix

Interletter confusion matrix for continuousline capital letters

\section{Tactile and Auditory}

Confusion matrix for tactually presented letters Confusion matrix for tactile letters generated by a $17 \times 17$ matrix of tactile stimulators

Tactile letter recognition under different modes of stimulus presentation using a $20 \times 20$ matrix of vibratory tactors placed against the back
62 Peabody Picture Vocabulary Test--Revised and 259 Snodgrass and Vanderwart (1980) pictures

Names corresponding to Snodgrass-Vanderwart's (1980) pictures

250 Snodgrass-Vanderwart's (1980) pictures

56 depth-rotated objects

22 novel figures

ESPbase

329 symbols

714 full-color images of depth-rotated objects

2,704 letter pairs

Lowercase letters of the alphabet

9 letters

Uppercase letters of the alphabet

Uppercase letters of the alphabet Uppercase letters of the alphabet Uppercase letters of the alphabet

Uppercase letters of the alphabet Uppercase letters of the alphabet

Block capital letters 
Table 1 (Continued)

\begin{tabular}{llll}
\hline \multicolumn{1}{c}{ Study } & \multicolumn{1}{c}{ Category } & \multicolumn{1}{c}{ Corpus } \\
\hline Loomis (1982) & $\begin{array}{l}\text { Confusion matrices for Braille letters and } \\
\text { characters presented as touch stimuli and } \\
\text { visual stimuli } \\
\text { Manning (1977) }\end{array}$ & & Uppercase letters and Braille \\
& $\begin{array}{l}\text { Auditory and visual similarity of consonants } \\
\text { RECALL AND RECOGNITION }\end{array}$ & English consonants and conson \\
Bell \& Shapiro (1971) & $\begin{array}{l}\text { Norms for organizational strategies in free } \\
\text { recall }\end{array}$ & 48 lists of 16 unrelated words \\
Butler \& Biner (1990) & $\begin{array}{l}\text { Recall norms of common spaces and activities } \\
\text { Christian, Bickley, Tarka, \& Clayton (1978) }\end{array}$ & $\begin{array}{l}\text { Measures of free recall of nouns } \\
\text { Stadler, Roediger, \& McDermott (1999) }\end{array}$ & Norms for word lists that create false memory 123 behaviors \\
\end{tabular}

WORD AND PICTURE NORMS FOR LANGUAGES OTHER THAN ENGLISH

\section{Chinese}

Mou \& Anderson (1981)

Rickard Liow, Tng, \& Lee (1999)

Alario \& Ferrand (1999)

Peereman \& Content (1999)

Ziegler, Jacobs, \& Stone (1996)

Algarabel, Ruiz, \& Sanmartin (1988)

Cuetos, Ellis, \& Alvarez (1999)

Sanfeliu \& Fernandez (1996)

Santiago, Justicia, Palma, Huertas, \& Gutiérrez (1996)

Fear (1997)

Arlinsky \& Epstein (1965)

Fearnley (1997)

Fuhrman, Bodenhausen, \& Lichtenstein (1989)

Hendrick, Hoving, \& Franz (1974)

Libkuman (1994)
Sets of Chinese characters and their pronunciations that varies as a function of whether the vowel is the same or different and the radical is the same or different

Semantic and phonetic regularity in Mandarin for China, Singapore, and Taiwan

\section{French}

Name agreement, familiarity, visual complexity, image variability, and age of acquisition for French

Orthography-phonology statistics for French monosyllabic words

Database for feedforward inconsistency (multiple ways to pronounce a spelling) and feedback inconsistency (multiple ways to spell a pronunciation)

\section{Spanish}

University of Valencia's computerized word pool

Naming times for pictures in Spanish

Picture standardized for Spanish for name agreement, image agreement, familiarity, and visual complexity

Surface word forms in Spanish

\section{Welsh}

Ratings of age of acquisition, familiarity, concreteness, and imageability for Welsh words and their English equivalents

\section{OTHER}

Frequency of grammatical classes in production of random strings and grammatically correct English sentences

Program that allows words to be extracted from the MRC Psycholinguistic database according to word length, number of syllables or phonemes, frequency of use, imageability, concreteness, meaning, etc.

Kindness, intelligence, goodness, and normality ratings for statements about social behaviors

Children's likableness ratings for common trait adjectives

Norms for generation of rhyme words
4 sets of 12 characters

256 semantic and 96 phonetic compound characters

400 pictures

\section{LEXOP lexical database}

Monosyllabic French words from the database

16,109 Spanish words

Snodgrass-Vanderwart (1980) pictures 254 Snodgrass-Vanderwart (1980) pictures

Spanish linguistic database

705 English and Welsh equivalent words

Produced strings and sentences of 11,22 , or 33 words

Medical Research Council (MRC)

Psycholinguistic Database of approximately 100,000 words

400 social behavior statements

22 trait adjectives

477 words 


\section{INDEX}

Alario, F.-X., \& Ferrand, L. (1999). A set of 400 pictures standardized for French: Norms for name agreement, image agreement, familiarity, visual complexity, image variability, and age of acquisition. $B e-$ havior Research Methods, Instruments, \& Computers, 31, 531-552.

Algarabel, S., Ruiz, J. C., \& Sanmartin, J. (1988). The University of Valencia's computerized word pool. Behavior Research Methods, Instruments, \& Computers, 20, 398-403.

Altarriba, J., Bauer, L. M., \& Benvenuto, C. (1999). Concreteness, context availability, and imageability ratings and word associations for abstract, concrete, and emotion words. Behavior Research Methods, Instruments, \& Computers, 31, 578-602.

AmSTER, H. (1967). Convergent association norms for ten-year-old children and college age adults. Psychonomic Monograph Supplements, 2 (1, Whole No. 17), 1-32

Amster, H., \& Keppel, G. (1966). Letter association norms. Psychonomic Monograph Supplements, 1 (9, Whole No. 9), 21 1-238.

ARLinsky, M., \& EPSTEIN, W. (1965). The frequency of grammatical classes in the production of verbal strings under two response sets. Psychonomic Science, 3, 555-556.

AshCRAFT, M. H. (1978). Property norms for typical and atypical items from 17 categories: A description and discussion. Memory \& Cognition, 6, 227-232.

Azuma, T. (1996). Familiarity and relatedness of word meanings: Ratings for 110 homographs. Behavior Research Methods, Instruments, \& Computers, 28, 109-124.

BELl, J. A., \& SHAPIRO, S. I. (1971). A normative study of organizational strategies in free recall learning. Psychonomic Monograph Supplements, 4 (1, Whole No. 49), 1-32.

Benjafield, J., Frommhold, K., Keenan, T., Muckenheim, R., \& MUELlER, D. (1993). Imagery, concreteness, goodness, and familiarity ratings for 500 proverbs sampled from the Oxford Dictionary of English Proverbs. Behavior Research Methods, Instruments, \& Computers, 25, 27-40.

Benjafield, J., \& MuCKenheim, R. (1989). Dates of entry and measures of imagery, concreteness, goodness, and familiarity for 1,046 words sampled from the Oxford English Dictionary. Behavior Research Methods, Instruments, \& Computers, 21, 31-52

Berman, S., Friedman, D., Hamberger, M., \& Snodgrass, J. G. (1989). Developmental picture norms: Relationships between name agreement, familiarity, and visual complexity for child and adult ratings of two sets of line drawings. Behavior Research Methods, Instruments, \& Computers, 21, 371-382.

Berndt, R. S., Reggia, J. A., \& Mitchum, C. C. (1987). Empirically derived probabilities for grapheme-to-phoneme correspondences in English. Behavior Research Methods \& Instrumentation, 19, 1-9.

BIERSDORFF, K. K., \& Solso, R. L. (1973). A recodification of the Palermo and Jenkins word-association norms. Behavior Research Methods \& Instrumentation, 5, 14-20.

Bjorklund, D. F., Thompson, B. E., \& Ornstein, P. A. (1983). Developmental trends in children's typicality judgments. Behavior Research Methods \& Instrumentation, 15, 350-356.

BLOOM, P. A., \& FISCHLER, I. (1980). Completion norms for 329 sentence contexts. Memory \& Cognition, 8, 631-642.

Boles, D. B., \& ClifForD, J. E. (1989). An upper- and lowercase alphabetic similarity matrix, with derived generation similarity values. $B e$ havior Research Methods \& Instrumentation, 21, 579-586.

Boutsen, L., LAmberTS, K., \& Verfaillie, K. (1998). Recognition times of different views of 56 depth-rotated objects: A note concerning Verfaillie and Boutsen (1995). Perception \& Psychophysics, 60, 900-907.

BowEN. J. H. (1971). The stability of the printed frequencies of occurrence of 420 English conceptual nouns. Psychonomic Science, 23, 156-158.

BRItTON, B. K. (1978). Lexical ambiguity of words used in English text. Behavior Research Methods \& Instrumentation, 10, 1-7.

Brown, G. D. A. (1984). A frequency count of 190,000 words in the London-Lund Corpus of English Conversation. Behavior Research Methods, Instruments, \& Computers, 16, 502-532.

BUtLER, D. L., \& Biner, P. M. (1990). Recall norms of common spaces and activities of college students. Behavior Research Methods, Instruments, \& Computers, 22, 3-12.
Chaffin, R. J. S., \& Herrmann, D. J. (1981). Comprehension of semantic relationships and the generality of categorization models. Bulletin of the Psychonomic Society, 17, 69-72.

Chiarello, C., Shears, C., \& Lund, K. (1999). Imageability and distributional typicality measures of nouns and verbs in contemporary English. Behavior Research Methods, Instruments, \& Computers, 31, 603-637.

Christian, J., Bickley, W., Tarka, M., \& Clayton, K. (1978). Measures of free recall of 900 English nouns: Correlations with imagery, concreteness, meaningfulness, and frequency. Memory \& Cognition, 6. $379-390$

Conley, P., Burgess, C., \& Hage, D. (1999). Large-scale database of proper names. Behavior Research Methods, Instruments, \& Computers, 31, 215-219.

Costantini, A. F., \& Blackwood, R. O. (1968). CCC trigrams of low association value: A re-evaluation. Psychonomic Science, 12, 67-68.

CoWAN, N. (1986). A matrix of consonant-cluster-free monosyllabic words in English. Behavior Research Methods, Instruments, \& Computers, 18, 434-446.

Craig, J. C. (1979). A confusion matrix for tactually presented letters. Perception \& Psychophysics, 26, 409-411.

Cuetos, F., Ellis, A. W., \& Alvarez, B. (1999). Naming times for the Snodgrass and Vanderwart pictures in Spanish. Behavior Research Methods, Instruments, \& Computers, 31, 650-658.

DALE, P. S., \& FENSON, L. (1996). Lexical development norms for young children. Behavior Research Methods, Instruments, \& Computers, 28, 125-127.

Danks, J. H. (1972). Associative responses to novel figures. Psychonomic Monograph Supplements, 4 (18, Whole No. 66), 319-325.

DE Bruijn, O., McDougall, S., \& Curry, M. B. (1999). ESPbase: A Microsoft Access tool for selecting symbol and icon sets for usability. Behavior Research Methods, Instruments, \& Computers, 31, 479-486.

DuNCAN, C. P., \& WOOD, G. (1966). Norms for successive word associations. Psychonomic Monograph Supplements, 1 (7, Whole No. 7), 203-206.

Erickson, J. R., GaffNey, C. R., \& HeATh, W. P. (1987). Difficulty and familiarity norms for 192 single-solution word fragments. Behavior Research Methods, Instruments, \& Computers, 19, 370-376.

FEAR, W. J. (1997). Ratings for Welsh words and their English equivalents. Behavior Research Methods, Instruments, \& Computers, 29, 425-445.

FEARNLEY, S. (1997). MRC Psycholinguistic Database search program. Behavior Research Methods, Instruments, \& Computers, 29, 291-295.

Ferraro, F. R., \& Kellas, G. (1990). Normative data for number of word meanings. Behavior Research Methods, Instruments, \& Computers, 22, 491-498.

Ferreira, V. S., \& Cutting, J. C. (1997). Ninety-three pictures and 108 questions for the elicitation of homophones. Behavior Research Methods, Instruments, \& Computers, 29, 619-635.

Friendly, M., Franklin, P. E., Hoffman, D., \& Rubin, D. C. (1982). The Toronto Word Pool: Norms for imagery, concreteness, orthographic variables, and grammatical usage for 1,080 words. Behavior Research Methods \& Instrumentation, 14, 375-399.

Fuhrman, R. W., Bodenhausen, G. V., \& Lichtenstein, M. (1989). On the trait implications of social behaviors: Kindness, intelligence, goodness, and normality ratings for 400 behavior statements. Behavior Research Methods, Instruments, \& Computers, 21, 587-597.

GarSKOF, B. E., Houston, J. P., \& MEDNiCK, S. A. (1967). Overlap and direct associative strength norms for $\mathbf{4 8 0}$ word pairs. Psychonomic Monograph Supplements, 2 (2, Whole No. 18), 33-38.

Gawlick-Grendell, L. A., \& WoltZ, D. J. (1994). Meaning dominance norms for 120 homographs. Behavior Research Methods, Instruments, \& Computers, 26, 5-25.

Geen, R. G., \& Stonner, D. (1975). Primary associates to 20 verbs connoting violence. Behavior Research Methods \& Instrumentation, 7, 391-392.

GeIS, M. F., \& WINOGRaD, E. (1974). Norms of semantic encoding variability for fifty homographs. Bulletin of the Psychonomic Society, $\mathbf{3}$, 429-431.

GerjouY, I. R., \& Gerjouy, H. (1965). Preliminary word-association norms for institutionalized adolescent retardates. Psychonomic Science, 2, 91-92.

GEYER, L. H. (1977). Recognition and confusion of the lowercase alphabet. Perception \& Psychophysics, 22, 487-490. 
Geyer, L. H., \& GuPTA, S. M. (1981). Recognition/confusion of dot matrix vs. conventional font capital letters. Perception \& Psychophysics, 29, 280-282.

GibSON, J. M., \& BRoOKS, J. O., III (1993). A collection of 4,741 word fragments that have unique completions with respect to 146,205 words. Behavior Research Methods, Instruments, \& Computers, 25, 434-454.

GiBson, J. M., \& WATKINS, M. J. (1988). A pool of 1,086 words with unique two-letter fragments. Behavior Research Methods, Instruments, \& Computers, 20, 390-397.

GiL.HOOLY, K. J. (1978). Bigram statistics for 205 five-letter words having single-solution anagrams. Behavior Research Methods \& Instrumentation, 10, 389-392.

Gilhooly, K. J., \& HAY, D. (1977). Imagery, concreteness, age-ofacquisition, familiarity, and meaningfulness values for 205 five-letter words having single-solution anagrams. Behavior Research Methods \& Instrumentation, 9, 12-17.

Gilhooly, K. J., \& LoGie, R. H. (1980a). Age-of-acquisition, imagery, concreteness, familiarity, and ambiguity measures for 1,944 words. Behavior Research Methods \& Instrumentation, 12, 395-427.

Gilhooly, K. J., \& LOGIE, R. H. (1980b). Meaning-dependent ratings of imagery, age of acquisition, familiarity, and concreteness for 387 ambiguous words. Behavior Research Methods \& Instrumentation, $12,428-450$

Gorfein, D. S., ViViani, J. M., \& LEDo, J. (1982). Norms as a tool for the study of homography. Memory \& Cognition, 10, 503-509.

GraF, P., \& Williams, D. (1987). Completion norms for 40 three-letter word stems. Behavior Research Methods, Instruments, \& Computers, 19, 422-445.

GrIfFIN, Z. M. (1999). Frequency of meaning use for ambiguous and unambiguous words. Behavior Research Methods, Instruments, \& Computers, 31, 520-530.

GRUENENFELDER, T. M. (1984). Typicality ratings for 893 exemplars of 93 categories. Behavior Research Methods, Instruments, \& Computers, 16, 351-354

Hamberger, M. J., Friedman, D., \& Rosen, J. (1996). Completion norms collected from younger and older adults for 198 sentence contexts. Behavior Research Methods, Instruments, \& Computers, 28, 102-108.

Hendrick, C., Hoving, K. L., \& Franz, C. M. (1974). Children's likableness ratings of 22 trait adjectives. Bulletin of the Psychonomic Society, 4, 91-92.

Hirata, K., \& Bryden, M. P. (1971). Tables of letter sequences varying in order of approximation to English. Psychonomic Science, 25, 322-324.

Hunt, K. [P.] (1977). Meaningfulness (m') values for $300 \mathrm{CCCs}$. Behavior Research Methods \& Instrumentation, 9, 469-470.

HUNT, K. [P.] (1978). Imagery values for taxonomic-category names. Behavior Research Methods \& Instrumentation, 10, 750-752.

HUNT, K. P., \& HodGE, M. H. (1971). Category-item frequency and category-name meaningfulness $\left(\mathrm{m}^{\prime}\right)$ : Taxonomic norms for 84 categories. Psychonomic Monograph Supplements, 4 (6, Whole No. 54), $97-121$.

JONES, G. V. (1980a). English palindromes: A distributional model. Behavior Research Methods \& Instrumentation, 12, 489-491.

JoNes, G. V. (1980b). Heteropalindromes. Behavior Research Methods \& Instrumentation, 12, 393-394.

KATZ, A. N. (1983). Dominance and typicality norms for properties: Convergent and discriminant validity. Behavior Research Methods \& Instrumentation, 15, 29-38.

KeEnan, T. R., \& Benjafield, J. G. (1994). An additional measure of availability derived from the Oxford English Dictionary. Psychonomic Bulletin \& Review, 1, 255-257.

KEREN, G., \& BAGGEN, S. (1981). Recognition models of alphanumeric characters. Perception \& Psychophvsics, 29, 234-246.

KerR, N. H., \& Johnson, T. H. (1991). Word norms for blind and sighted subjects: Familiarity, concreteness, meaningfulness, imageability, imagery modality, and word associations. Behavior Research Methods, Instruments, \& Computers, 23, 461-485.

Kikuchi, T., Yamashita, Y., Sagawa, K., \& Wake, T. (1979). An analysis of tactile letter confusions. Perception \& Psychophysics, 26, 295-301.

Lachman, R., \& LaUGHERY, K. R. (1965). Letter association and sequence norms. Psychonomic Science, 2, 103-104.
Ley, R., \& Karker, J. (1974). Pronunciability ratings of 319 CVCVC words and paralogs previously assessed for meaningfulness and associative reaction time. Bulletin of the Psychonomic Society, 3, 42 1-424.

LEY, R., \& TESINY, E. (1975). Associative reaction time, meaningfulness, and pronunciability ratings of 382 words and paralogs. Bulletin of the Psychonomic Society, 6, 645-648.

LiBkuman, T. M. (1994). Norms for words that rhyme. Behavior Research Methods, Instruments, \& Computers, 26, 278-322.

LippMAN, L. G., \& KINTZ, B. L. (1968). Group predictions of item differences of CVC trigrams. Psychonomic Science, 12, 265-266.

Loess, H., Brown, A., \& Campbell, J. (1969). Cultural norms for items in 30 taxonomic categories. Psychonomic Monograph Supplements, 3 (7, Whole No. 39), 69-86.

LoOMIs, J. M. (1974). Tactile letter recognition under different modes of stimulus presentation. Perception \& Psychophysics, 16, 401-408.

Loomis, J. M. (1982). Analysis of tactile and visual confusion matrices. Perception \& Psychophysics, 31, 41-52.

Lovelace, E. A., Reid, L. S., \& Hunt, L. C. (1981). Free associations to conceptually structured word triads. Bulletin of the Psychonomic Society, 17, 65-68.

MANNING, S. K. (1977). Ratings of the auditory and visual similarity of consonants: Implications for research. Behavior Research Methods \& Instrumentation, 9, 495-498.

MarIDAKI-KassotaKI, K. (1997). Are rating-based procedures reliable for derivation of typicality judgments from children? Behavior Research Methods, Instruments, \& Computers, 29, 376-385.

Martin, M., Jones, G. V., Nelson, D. L.. \& Nelson, L. (1981). Heteronyms and polyphones: Categories of words with multiple phonemic representations. Behavior Research Methods \& Instrumentation, 13, 299-307.

MayznER, M. S., \& Tresselt, M. E. (1965). Tables of single-letter and digram frequency counts for various word-length and letter-position combinations. Psychonomic Monograph Supplements, 1 (2, Whole No. 2), 13-32.

Mayzner, M. S., Tresselt, M. E., \& Wolin, B. R. (1965a). Tables of trigram frequency counts for various word-length and letter-position combinations. Psychonomic Monograph Supplements, 1 (3, Whole No. 3), 33-78

Mayzner, M. S., Tresselt, M. E., \& Wolin, B. R. ( 1965b). Tables of tetragram frequency counts for various word-length and letter-position combinations. Psychonomic Monograph Supplements, 1 (4, Whole No. 4), 79-142.

Mayzner, M. S., Tresselt, M. E., \& Wolin, B. R. (1965c). Tables of pentagram frequency counts for various word-length and letter-position combinations. Psychonomic Monograph Supplements, 1 (5, Whole No. 5), 145-185.

McDougall, S. J. P., Curry, M. B., \& de Bruijn, O. (1999). Measuring symbol and icon characteristics: Norms for concreteness, complexity, meaningfulness, familiarity, and semantic distance for 239 symbols. Behavior Research Methods, Instruments, \& Computers, 31 , 487-519.

Mou, L.-C., \& ANDERson, N. S. (1981). Graphemic and phonemic codings of Chinese characters in short-term retention. Bulletin of the Psychonomic Society, 17, 255-258.

Nelson, D. L., McEvoy, C. L., WAlling, J. R., \& Wheeler, J. W., JR. (1980). The University of South Florida homograph norms. Behavior Research Methods \& Instrumentation, 12, 16-37.

Nickerson, C. A., \& CarTwright, D. S. (1984). The University of Colorado meaning norms. Behavior Research Methods, Instruments, \& Computers, 16, 355-382.

NoBle, C. E. (1967). Comparative pronounceability ratings (p) of 100 CVCs in two college populations. Psychonomic Science, 8, 433-434.

NoDine, C. F., \& HARDT, J. V. (1969). A measure of pronunciability of CVC trigrams. Behavior Research Methods \& Instrumentation, 1 , $210-216$.

Olson, G. A., \& KausLer, D. H. (1971), Orthographic distinctiveness of homonyms. Behavior Research Methods \& Instrumentation, 3, 298-299.

Olson, R., \& SCHWARTZ, R. (1967). Single and multiple solution fiveletter words. Psychonomic Monograph Supplements, 2 (8, Whole No. 24), 105-152.

Peereman, R., \& Content, A. (1999). LEXOP: A lexical database pro- 
viding orthography-phonology statistics for French monosyllabic words. Behavior Research Methods, Instruments, \& Computers, 31, 376-379.

Posnansky, C. J. (1978). Category norms for verbal items in 25 categories for children in Grades 2-6. Behavior Research Methods \& Instrumentation, 10, 819-832.

Rickard Liow, S. J., TNG, S. K., \& Lee, C. L. (1999). Chinese characters: Semantic and phonetic regularity norms for China, Singapore, and Taiwan. Behavior Research Methods, Instruments, \& Computers, 31, 155-177.

RoberTs, D. M. (1968). Meaningfulness of Underwood and Richardson's (1956a) sense impression descriptive adjectives. Psychonomic Science, 13, 121-122.

Rubin, D. C. (1981). First-order approximation to English, second-order approximation to English, and orthographic neighbor ratio norms for 925 nouns. Behavior Research Methods \& Instrumentation, 13, 713-721.

RudELL, A. P. (1993). Frequency of word usage and perceived word difficulty: Ratings of Kučera and Francis words. Behavior Research Methods, Instruments, \& Computers, 25, 455-463.

Sanfeliu, M. C., \& Fernandez, A. (1996). A set of 254 SnodgrassVanderwart pictures standardized for Spanish: Norms for name agreement, image agreement, familiarity, and visual complexity. Behavior Research Methods, Instruments, \& Computers, 28, 537-555.

Santiago, J., Justicia, F., Palma, A., Huertas, D., \& Gutiérrez, N. (1996). Lex I and II: Two databases of surface word forms for psycholinguistic research in Spanish. Behavior Research Methods, Instruments, \& Computers, 28, 418-426.

Schwanenflugel, P. J. (1986). Completion norms for final words of sentences using a multiple production measure. Behavior Research Methods, Instruments, \& Computers, 18, 363-371.

SCOTT, D., \& BADDELEY, A. D. (1969). Acoustic confusability values for 1172 CCC trigrams. Psychonomic Science, 14, 189-190.

Shapiro, S. I.. \& Palermo, D. S. (1968). An atlas of normative free association data. Psychonomic Monograph Supplements, 2 (12, Whole No. 28), 219-250.

Shapiro, S. I., \& Palermo, D. S. (1970). Conceptual organization and class membership: Normative data for representatives of 100 categories. Psvchonomic Monograph Supplements, 3 (11, Whole No. 43), 107-127.

ShaPIRo, S. S. (1964). Meaningfulness values for 52 CVCs for gradeschool-aged children. Psychonomic Science, 1, 127-128.

ShapIRo, S. S. (1966). Word association norms: Stability of response and chains of association. Psychonomic Science, 4, 233-234.

SHAW, R. J. (1997). Unprimed stem completion is only moderately predicted by word frequency and length. Behavior Research Methods, Instruments, \& Computers, 29, 401-424.

SNODGRass, J. G.. \& POSTER, M. (1992). Visual-word recognition thresholds for screen-fragmented names of the Snodgrass and Vanderwart pictures. Behavior Research Methods, Instruments, \& Computers, 24, $1-15$.

SNODgRass, J. G., \& Yuditsky, T. (1996). Naming times for the Snodgrass and Vanderwart pictures. Behavior Research Methods, Instruments, \& Computers, 28, 516-536.

Solso, R. L. (1971). Meaningfulness of colors. Psychonomic Science, 23, 301-303.

Solso, R. L. (1979). Positional frequency and versatility of letters for six-, seven-, and eight-letter English words. Behavior Research Methods \& Instrumentation, 11, 355-358.

Solso, R. L., Barbuto, P. F., JR., \& Juel, C. L. (1979). Bigram and trigram frequencies and versatilities in the English language. Behavior Research Methods \& Instrumentation, 11, 475-484.

Sol.so, R. L., \& JUEL. C. L. (1980). Positional frequency and versatility of bigrams for two- through nine-letter English words. Behavior Research Methods \& Instrumentation, 12, 297-343.

Solso, R. L., \& KinG, J. F. (1976). Frequency and versatility of letters in the English language. Behavior Research Methods \& Instrumentation, 8, 283-286.

Stadler, M. A., Roediger, H. L., III, \& McDermott, K. B. (1999). Norms for word lists that create false memories. Memory \& Cognition, 27, 495-500.
STADTLANDER, L. M. (1997). A compilation of 800 word neighborhoods by frequency. Behavior Research Methods, Instruments, \& Computers, 29, 636-644.

STARK, K. (1972). Synonym responses to 100 free association stimuli. Psychonomic Monograph Supplements, 4 (16, Whole No. 64), 269-274.

Stratton, R. P., Jacobus, K. A., \& Brinley, B. (1975). Age-ofacquisition, imagery, familiarity and meaningfulness norms for 543 words. Behavior Research Methods \& Instrumentation, 7, 1-6.

Surprenant, A. M., Hura, S. L., Harper, M. P., Jamieson, L. H., Long, G., Thede, S. M., Rout, A., Hsueh, T.-H., Hockema, S. A., Johnson, M. T., Srinivasan, P. N., White, C. M., \& Laflen, J. B. (1999). Familiarity and pronounceability of nouns and norms. Behavior Research Methods, Instruments, \& Computers, 31, 638-649.

TAYLOR, K. B. (1970). An information-theory measurement of CVC trigram meaningfulness. Psychonomic Science, 21, 101-103.

Topper, G. E., MaceY, W. H., \& Solso, R. L. (1973). Bigram versatility and bigram frequency. Behavior Research Methods \& Instrumentation, 5, 51-53.

TownSEND, J. T. (1971a). Alphabetic confusion: A test of models for individuals. Perception \& Psychophysics, 9, 449-454.

Townsend, J. T. (197lb). Theoretical analysis of an alphabetic confusion matrix. Perception \& Psychophysics, 9, 40-50.

TRESSElt, M. E., \& MAYZNER, M. S. (1964). The Kent-Rosanoff word association: Word association norms as a function of age. Psychonomic Science, 1, 65-66.

Tresselt, M. E., \& Mayzner, M. S. (1966). Normative solution times for a sample of 134 solution words and 378 associated anagrams. Psychonomic Monograph Supplements, 1 (15, Whole No. 15), 293-298.

Twilley, L. C., Dixon, P., TAYlor, D., \& Clark, K. (1994). University of Alberta norms of relative meaning frequency for 566 homographs. Memory \& Cognition, 22, 111-126.

Uyeda, K. M., \& MANDLER, G. (1980). Prototypicality norms for 28 semantic categories. Behavior Research Methods \& Instrumentation, 12, 587-595.

van der Heidden, A. H. C., Malhas, M. S. M., \& van den Roovaart, B. P. (1984). An empirical interletter confusion matrix for continuousline capitals. Perception \& Psychophysics, 35, 85-88.

Verfalllie, K., \& Boutsen, L. (1995). A corpus of 714 full-color images of depth-rotated objects. Perception \& Psychophvsics, 57, 925-961.

WALKER, H. J. (1970). Imagery ratings for 338 nouns. Behavior Research Methods \& Instrumentation, 2, 165-167.

Warren, R. E., Bresnick, J. H., \& Green, J. P. (1977). Definitional dominance distributions for 20 English homographs. Bulletin of the Psychonomic Society, 10, 229-231.

Whalen, D. H., \& Zsiga, E. C. (1994). Subjective familiarity of English word/name homophones. Behavior Research Methods, Instruments, \& Computers, 26, 402-408.

Wilson, M. (1988). MRC Psycholinguistic Database: Machine-usable dictionary, version 2.00. Behavior Research Methods, Instruments, \& Computers, 20, 6-10.

WiNTERS, J. J., JR., \& KAHN, H. (1970). Word association norms of adolescent mental retardates. Psychonomic Monograph Supplements, 3 (8, Whole No. 40), 87-94.

WINTERS, J. J., JR., \& KAHN, H. (1971). Word-association norms: A comparison of adolescent mental retardates and normals. Psychonomic Monograph Supplements, 4 (8, Whole No. 56), 129-163.

Wollen, K. A., Cox, S. D., Coahran, M. M., Shea, D. S., \& Kirby, R. F. (1980). Frequency of occurrence and concreteness ratings of homograph meanings. Behavior Research Methods \& Instrumentation, 12, 8-15.

Zechmeister, E. B., King, J., Gude, C., \& Opera-Nadi, B. (1975). Ratings of frequency, familiarity, orthographic distinctiveness and pronunciability for 192 surnames. Behavior Research Methods \& Instrumentation, 7, 531-533.

Ziegler, J. C., JACOBS, A. M., \& Stone, G. O. (1996). Statistical analysis of the bidirectional inconsistency of spelling and sound in French. Behavior Research Methods, Instruments, \& Computers, 28, 504-515.

Ziegler, J. C.. Stone, G. O., \& JaCobs, A. M. (1997). What is the pronunciation for -ough and the spelling for $/ \mathrm{u} / ?$ A database for computing feedforward and feedback consistency in English. Behavior Research Methods, Instruments, \& Computers, 29, 600-618. 